\title{
EFEKTIVITAS PERENDAMAN BENIH DALAM AIR PANAS TERHADAP DAYA KECAMBAH DAN PERTUMBUHAN BIBIT ADAS (Foeniculum vulgare Mill)
}

\author{
Riya Wahyu Sriwigati ${ }^{1}$, Mohamad Ihsan ${ }^{2}$, Libria Widiastuti ${ }^{2}$ \\ 1) Fakultas Pertanian Universitas Islam Batik Surakarta, JI. KH Agus Salim No.10 Surakarta, \\ riyawscout99@gmail.com \\ 2) Fakultas Pertanian Universitas Islam Batik Surakarta, JI. KH Agus Salim No.10 Surakarta, \\ airakiranahebat@gmail.com
}

\begin{abstract}
Abstrak
Observasi ini memiliki sasaran untuk mengetahui dampak perendaman benih dengan suhu air panas dan lama perendaman terhadap viabilitas benih adas dan pertumbuhan bibit adas (Foeniculum vulgare Mill). Observasi ini telah berlangsung pada bulan Oktober hingga bulan Desember 2020, di Dusun Manggung RT 02 RW 04 Desa Sukorejo, Kecamatan Musuk, Kabupaten Boyolali. Ketinggian lokasi $\pm 800 \mathrm{~m}$ dpl. Observasi ini memakai rancangan lingkungan dalam pola dasar Rancangan Acak Lengkap (RAL) disusun oleh dua faktor yang diulang sejumlah tiga kali. Faktor pertama adalah perendaman dengan suhu air panas, yang terdiri atas tiga taraf $\left(P_{1}: 50^{\circ} \mathrm{C}, \mathrm{P}_{2}: 60^{\circ} \mathrm{C}\right.$, serta $\left.\mathrm{P}_{3}: 70^{\circ} \mathrm{C}\right)$. Faktor kedua yaitu lama perendaman yang tersusun atas 3 macam $\left(W_{1}: 10\right.$ menit, $W_{2}: 15$ menit, serta $W_{3}: 20$ menit). Parameter pengamatan terdiri atas jumlah benih berkecambah, daya berkecambah, tinggi tanaman, jumlah helai daun, panjang akar, serta berat bibit segar. Hasil observasi menunjukan : Perlakuan perendaman dengan suhu air panas memberikan dampak nyata berkenaan dengan jumlah benih berkecambah. Dan berdampak amat nyata berkenaan dengan daya berkecambah, tinggi tanaman, jumlah daun, panjang akar, dan berat bibit segar. Perlakuan lama perendaman berdampak nyata berkenaan dengan parameter jumlah benih berkecambah dan daya berkecambah dan berdampak tidak nyata pada parameter lainnya. Kombinasi perlakuan $\mathrm{P}_{2} \mathrm{~W}_{1}$ mampu mematahkan dormansi benih adas dengan baik hingga mencapai daya kecambah $100 \%$. Interaksi perlakuan P x W menunjukkan pengaruh tidak nyata pada parameter lainnya.
\end{abstract}

Kata kunci: Adas, daya kecambah, perendaman, air panas

\begin{abstract}
This study aims to determine the effect of submersion seeds in hot water and submersion time on the viability of fennel seeds and growth of fennel seeds (Foeniculum vulgare Mill). This research was conducted from October to December 2020, in Manggung Village RT 02 RW 04 Sukorejo Village, Musuk District, Boyolali Regency. Altitude $\pm 800 \mathrm{~m}$ asl. This study uses an environmental design in the basic pattern of Completely Randomized Design (CRD) arranged factually with 2 (two) factors repeated 3 (three) times. The first factor is submersion seeds in hot water, which consists of three levels (P1: 50ㅇ $\mathrm{C}, \mathrm{P2}$ : $60^{\circ} \mathrm{C}$, and P3: $70^{\circ} \mathrm{C}$ ). The second factor was the submersion time which consisted of 3 kinds of treatments (W1: 10 minutes, W2: 15 minutes, and W3: 20 minutes). The observation parameters consisted of the number of seeds germinating, germination capacity, plant height, number of leaves, root length, and weight of fresh seeds. The results showed that: Submersion treatment with hot water had a significant effect on the number of germinated seeds. And had a very significant effect on germination, plant height, number of leaves, root length, and weight of fresh seeds. The treatment of submersion time had a significant effect on the parameters of the number of seeds germinated and the germination capacity and had no significant effect on other parameters. The combination of P2W1 treatment (submersion with hot water temperature of $60^{\circ} \mathrm{C}$ and submersion time for 10 minutes) was able to break the dormancy of fennel seeds well until they reached $100 \%$ germination. The $P \times W$ treatment interaction showed no significant effect on other parameters.
\end{abstract}

Keywords: fennel, germination, submersion, hot water

\section{PENDAHULUAN}

Adas (Foeniculum vulgare Mill.) industri dan sektor pangan di Indonesia. Adas merupakan tanaman herbal sekaligus tanaman berguna sebagai bahan dasar farmasi, makeup rempah yang banyak dipakai pada sektor dan jamu di sektor industri. Daunnya 
dikonsumsi menjadi sayuran, dan bijinya sebagai bahan dasar bumbu dapur (Hidayat dan Napitupulu, 2015). Minyak atsiri adalah produk utama adas. Senyawa aktif bahan baku pembuatan obat salah satunya adalah minyak atsiri (Wahyuningsih, 2014).

Sebagai tanaman yang memiliki banyak kandungan kimia dan berkhasiat, penggunaan simplisia adas untuk bahan baku obat terus meningkat. Seiring dengan peningkatan penggunaan simplisia adas, maka kebutuhan simplia ini semakin tinggi. Guna mencukupi kebutuhan simplisia adas yang semakin tinggi tersebut maka diperlukan strategi penyediaan stok produksi simplisia yang cukup dan berkesinambungan. Salah satu alternatifnya dengan pengelolaan teknik budidaya serta pengelolaan pasca panen yang baik dan benar (Hasanah, 2004).

Tanaman adas umumnya diperbanyak secara generatif (benih). Ketergantungan produksi benih adas dalam alam mengakibatkan penyimpanan benih berperan penting. Penyimpanan merupakan tahapan kritis yang berdampak terhadap mutu benih (Setyaningsih, 2002). Untuk meningkatkan produksi diperlukan benih yang bermutu dan memiliki viabilitas yang seragam. Ketumbar, purwoceng dan adas merupakan tanaman dari famili Apiaceae yang memiliki viabilitas (daya kecambah) rendah di bawah $70 \%$. Tanaman adas merupakan kelompok benih ortodoks, adalah benih yang membutuhkan kadar air rendah, supaya viabilitas benih mampu dijaga sewaktu penyimpanan. Perlakuan terhadap benih sebelum ditanam seperti perendaman dalam larutan $P E G / K N O_{3}$, perendaman dengan air panas, dan zat pengatur tumbuh berguna untuk meningkatkan viabilitas. Hasil penelitian Ani (2006) menunjukkan dampak perendaman benih dengan air panas berkenaan dengan daya kecambah pada benih lamtoro dapat mencapai persentase perkecambahan $75 \%$ adalah perlakuan suhu air awal $70^{\circ} \mathrm{C}$. Penelitian Setyaningsih (2002) menunjukkan peningkatan viabilitas benih adas sampai $68,30 \%$ diperoleh pada perlakuan osmoconditioning-PEG (-1 Mpa) dengan benih dari buah yang berwarna hijau. Rusmin dkk., (2011) menunjukkan peningkatan daya kecambah benih purwoceng sebanyak dua kali lipat terjadi pada perendaman dalam larutan GA3 400 ppm selama 48 jam.

\section{BAHAN DAN METODE}

Penelitian dilakukan di Dusun Manggung RT 02 RW 04 Desa Sukorejo, Kecamatan Musuk, Kabupaten Boyolali dengan ketinggian $\pm 800 \mathrm{~m}$ dpl pada bulan Oktober hingga bulan Desember 2020. Alat yang digunakan untuk penelitian adalah cangkul atau sekop, paranet, papan nama, alat tulis, kamera, ember, baskom, gembor, penggaris, thermometer, gelas, timbangan dan polybag. Bahan yang digunakan adalah benih adas, tanah, arang sekam dan pupuk yang berasal dari kotoran hewan (kambing). Observasi ini memakai Rancangan Acak Lengkap (RAL) tiga ulangan. Terdapat dua macam perlakuan yang diteliti yaitu perendaman dengan suhu air panas dan lama perendaman. Faktor perlakuan perendaman dengan suhu air panas $(P)$, terdiri dari tiga faktor perlakuan yaitu : $P_{1}: 50^{\circ} \mathrm{C}, \mathrm{P}_{2}$ : $60^{\circ} \mathrm{C}$, dan $\mathrm{P}_{3}: 70^{\circ} \mathrm{C}$. Faktor perlakuan waktu/lama perendaman $(\mathrm{W})$, terdiri dari tiga faktor perlakuan yaitu : $W_{1}: 10$ menit, $W_{2}: 15$ menit, dan $\mathrm{W}_{3}: 20$ menit.

Parameter yang diamati adalah jumlah benih berkecambah, daya berkecambah, tinggi tanaman, jumlah helai daun, panjang akar, serta berat bibit segar.

\section{HASIL DAN PEMBAHASAN}

Perlakuan perendaman dengan suhu air berpengaruh nyata pada parameter jumlah benih berkecambah. Dan berpengaruh sangat nyata pada parameter lainnya. Perlakuan waktu perendaman berpengaruh nyata pada parameter: jumlah benih berkecambah dan daya berkecambah, namun tidak berpengaruh nyata pada parameter lainnya. Interaksi perlakuan perendaman dalam air panas dan perlakuan lama perendaman berpengaruh tidak nyata pada parameter : jumlah benih 
Agrisaintifika

Jurnal Ilmu-Ilmu Pertanian

Vol. 5, No. 1, 2021

Sriwigati, et al. 2021

berkecambah, tinggi tanaman, jumlah helai daun, panjang akar, serta berat bibit segar. Hal ini disajikan pada tabel 1.

Perlakuan perendaman dengan suhu air panas memberikan interaksi terbaik pada pertumbuhan bibit. Hal ini disebabkan karena suhu $70^{\circ} \mathrm{C}$ mampu mempercepat proses imbibisi. Proses imbibisi yang baik ini kemudian akan meningkatkan daya berkecambah. Hal ini sesuai dengan hasil penelitian Hidayat dan Marjani (2017) peningkatan daya berkecambah benih yute metode aturan yang efektif dan mudah diaplikasikan adalah dengan perendaman suhu air panas $80^{\circ} \mathrm{C}$ dalam waktu tiga jam. Pertumbuhan bibit lebih baik pada perlakuan perendaman dengan suhu $60^{\circ} \mathrm{C}$ dan dan $70^{\circ} \mathrm{C}$. Hal ini diduga karena meningkatnya kecepatan berkecambah ( 7 hari) sejalan

dengan ketersediaan faktor eksternal (lingkungan tumbuh) membantu bibit untuk tumbuh lebih cepat. Menurut Sugito (2012) faktor eksternal yang mempengaruhi pertumbuhan tanaman adalah suhu, cahaya matahari, tanah, hara dan air.

Perlakuan lama perendaman berpengaruh nyata pada parameter: jumlah benih berkecambah dan daya berkecambah, namun tidak berdampak nyata pada parameter lainnya. Peristiwa ini karena waktu perendaman hanya dilakukan pada saat perlakuan benih, sehingga tidak memberikan pengaruh nyata pada pertumbuhan bibit. Sugito (2012) menyataan bahwa faktor eksternal yang mempengaruhi pertumbuhan tanaman adalah suhu, cahaya matahari, tanah, hara dan air.

Tabel 1. Rangkuman hasil penelitian

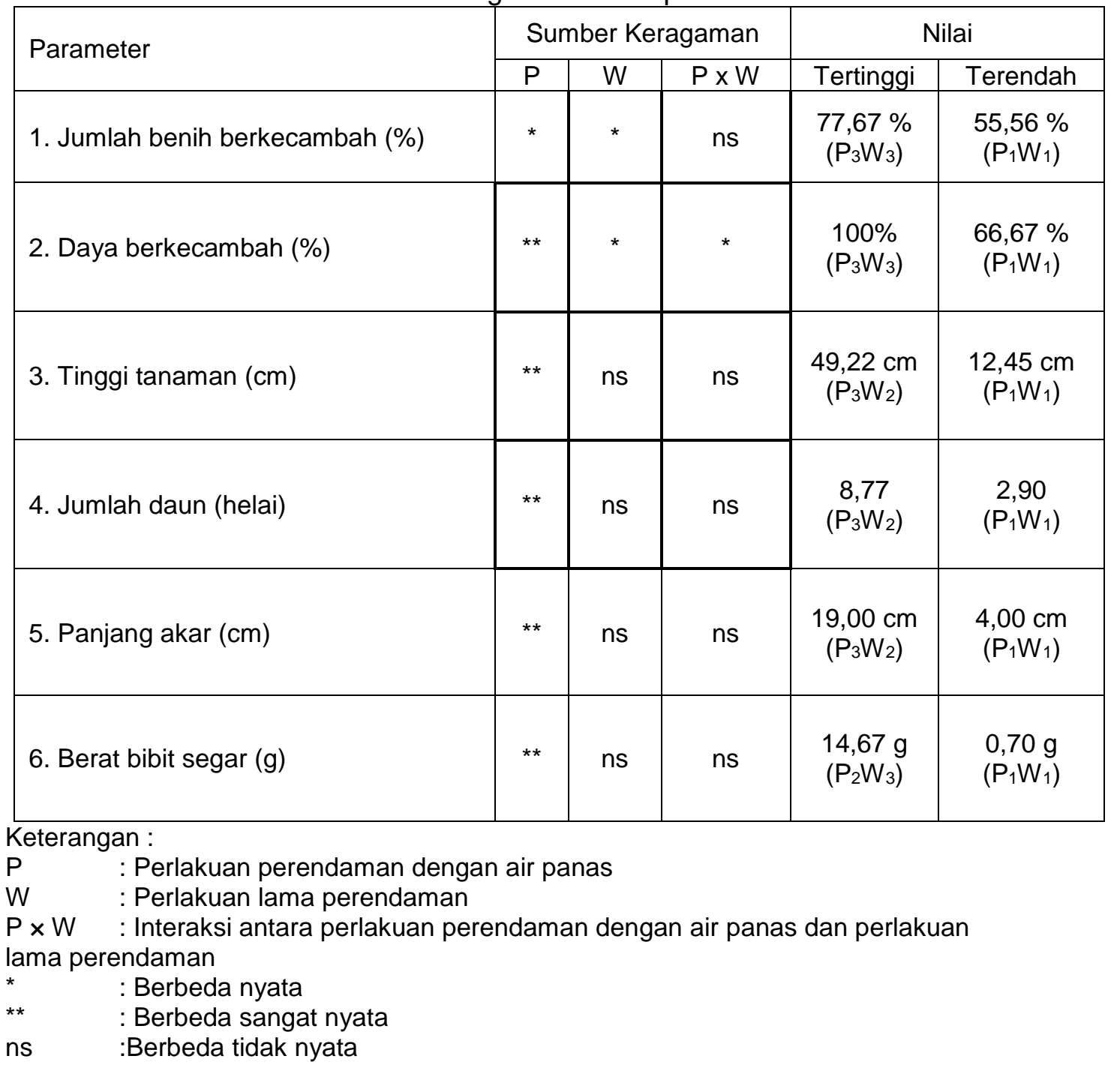


Interaksi perlakuan perendaman dengan air panas dan lama perendaman menunjukkan pengaruh tidak nyata terhadap parameter pengamatan jumlah benih berkecambah, tinggi tanaman, jumlah daun, panjang akar, dan berat bibit segar. Hal ini dapat disimpulkan bahwa interaksi antara perendaman dengan air panas dan perlakuan lama perendaman tidak saling bersinergi dalam pertumbuhan bibit adas. Namun interaksi perlakuan perendaman dengan air panas dan perlakuan lama perendaman menunjukkan dampak nyata terhadap daya berkecambah.

Peristiwa ini disebabkan karena suhu $70^{\circ} \mathrm{C}$ dan lama perendaman 20 menit mampu mempercepat proses imbibisi. Proses imbibisi yang baik ini kemudian akan meningkatkan daya berkecambah. Hal ini sesuai dengan hasil penelitian Taufiq Hidayat-R.S. dan Marjani (2017) peningkatan daya berkecambah benih yute metode aturan yang efektif dan mudah diaplikasikan adalah dengan perendaman suhu air panas $80^{\circ} \mathrm{C}$ dalam waktu tiga jam.

\section{SIMPULAN}

Dari hasil penelitian tentang Efektivitas Perendaman Benih Dalam Air Panas Terhadap Daya Kecambah Dan Pertumbuhan Bibit Adas (Foeniculum vulgare Mill), dapat disimpulkan :

1. Perlakuan perendaman dengan suhu air panas memberikan pengaruh nyata terhadap jumlah benih berkecambah dan menunjukkan pengaruh sangat nyata terhadap daya kecambah, tinggi tanaman, jumlah daun, panjang akar, dan berat bibit segar.

2. Perlakuan lama perendaman memberikan pengaruh nyata terhadap parameter jumlah benih berkecambah dan daya berkecambah namun berpengaruh tidak nyata pada parameter lainnya.
3. Kombinasi perlakuan $\mathrm{P}_{2} \mathrm{~W}_{1}$ yaitu perendaman dengan suhu air panas $60^{\circ} \mathrm{C}$ selama 10 menit mampu mematahkan dormansi benih adas dengan baik hingga mencapai daya kecambah $100 \%$. Interaksi perlakuan P x $\mathrm{W}$ menunjukkan pengaruh tidak nyata pada parameter jumlah benih berkecambah, tinggi tanaman, jumlah daun, panjang akar, dan berat bibit segar.

\section{DAFTAR PUSTAKA}

Ani, N. (2006). Pengaruh Perendaman Benih Dalam Air Panas Terhadap Daya Kecambah Dan Pertumbuhan Bibit Lamtoro (Leucaena leucocephala). Jurnal IImu Penelitian Bidang IImu Pertanian, 4(1).

Hasanah, M. (2004). Perkembangan Teknologi Budidaya Adas (Foeniculum vulgare Mill.). Jurnal Litbang Pertanian.

Hidayat, S. dan R. Napitupulu. (2015). Kitab Tumbuhan Obat. Jakarta: Penebar Swadaya.

Hidayat-R.S, Taufiq . dan Marjani. (2017). Teknik pematahan dormansi untuk meningkatkan daya berkecambah dua aksesi benih yute (Corchorus olitorius L.). Malang: Jurnal Litbang Pertanian.

Rusmin, D., F.C. Suwarno dan I. Darwati. (2011). Pengaruh Pemberian Ga3 Pada Berbagai Konsentrasi Dan Lama Imbibisi Terhadap Peningkatan Viabilitas Benih Purwoceng (Pimpinella pruatjan Molk). Jurnal Littri, 15 (1) : 40 45.

Setyaningsih, M. C. (2002). Pengaruh Tingkat Masak, Penyimpanan Dan Invigorisasi Terhadap Perubahan Fisiologis Benih Adas (Forniculum vulgare Mill). Bogor: Institut Pertanian Bogor.

Siregar, Benedicta Lamria. (2013). Perkecambahan dan pematahan dormansi benih andaliman (Zanthoxylum acanthopodium DC.). Medan: Jurnal Universitas HKBP Nommensen. 
Sugito, Y. (2012). Ekologi Tanaman. Malang: Universitas Brawijaya Press.

Widajati, E., Murniati, E., Palupi, ER., Kartika, T., Suhartanto, MR., dan Qadir, A.
(2013). Dasar Ilmu Dan Tekologi Benih. Bogor: PT Penerbit IPB Press.

Zuhud. (2014). Buku Acuan Umum Tumbuhan Obat Indonesia Jilid III. Jakarta: Dian Rakyat. 